\title{
Alkaloids from Prosopis juliflora leaves induce glial activation, cytotoxicity and stimulate NO production.
}

\author{
A.M.M. Silva ${ }^{a}$, A.R. Silva ${ }^{\mathrm{a}}$, A.M. Pinheiro ${ }^{\mathrm{a}}$, S.R.V.B. Freitas ${ }^{\mathrm{a}}$, V.D.A. Silva ${ }^{\mathrm{a}}$, \\ C.S. Souza ${ }^{a}$, J.B. Hughes ${ }^{a}$, R.S. El-Bacháa ${ }^{\text {, M.F.D. Costa }}{ }^{\mathrm{a}}$, E.S. Velozo ${ }^{\mathrm{b}}$, \\ M. Tardy ${ }^{\mathrm{c}}$, S.L. Costa ${ }^{\mathrm{a}, *}$ \\ ${ }^{a}$ Laboratório de Neuroquímica e Biologia Celular, Departamento de Biofunção, Instituto de Ciências da Saúde, \\ Universidade Federal da Bahia, Salvador, BA, 40.110-100, Brazil \\ ${ }^{\mathrm{b}}$ Laboratório de Pesquisa em Matéria Médica, Faculdade de Farmácia, Universidade Federal da Bahia (UFBA), Salvador, BA, \\ 40170-290, Brazil \\ ${ }^{\mathrm{c}}$ Université Paris XII Val de Marne Faculté de Médicine, Rue du Géneral Sarrail, 94010, Val-de-Marne, Créteil, Cedex, France
}

Received 27 April 2006; received in revised form 21 July 2006; accepted 25 July 2006

Available online 17 August 2006

\begin{abstract}
Prosopis juliflora is used for feeding cattle and humans. Intoxication with the plant has been reported, and is characterized by neuromuscular alterations and gliosis. Total alkaloidal extract (TAE) was obtained using acid/basicmodified extraction and was fractionated. TAE and seven alkaloidal fractions, at concentrations ranging $0.03-30 \mu \mathrm{g} / \mathrm{ml}$, were tested for $24 \mathrm{~h}$ on astrocyte primary cultures derived from the cortex of newborn Wistar rats. The MTT test and the measure of LDH activity on the culture medium, revealed that TAE and fractions F29/30, F31/33, F32 and F34/35 were cytotoxic to astrocytes. The $\mathrm{EC}_{50}$ values for the most toxic compounds, TAE, F31/33 and F32 were 2.872 .82 and 3.01 $\mu \mathrm{g} / \mathrm{ml}$, respectively. Morphological changes and glial cells activation were investigated through Rosenfeld's staining, by immunocytochemistry for the protein OX-42, specific of activated microglia, by immunocytochemistry and western immunoblot for GFAP, the marker of reactive and mature astrocytes, and by the production of nitric oxide (NO). We observed that astrocytes exposed to $3 \mu \mathrm{g} / \mathrm{ml} \mathrm{TAE}, \mathrm{F} 29 / 30$ or F31/33 developed compact cell body with many processes overexpressing GFAP. Treatment with $30 \mu \mathrm{g} / \mathrm{ml}$ TAE and fractions, induced cytotoxicity characterized by a strong cell body contraction, very thin and long processes and condensed chromatin. We also observed that when compared with the control $( \pm 1.34 \%)$, the proportion of OX-42 positive cells was increased in cultures treated with $30 \mu \mathrm{g} / \mathrm{ml} \mathrm{TAE}$ or F29/30, F31/33, F32 and F34/35, with values raging from $7.27 \%$ to $28.74 \%$. Moreover, incubation with $3 \mu \mathrm{g} / \mathrm{ml} \mathrm{F32,} 30 \mu \mathrm{g} / \mathrm{ml}$ TAE, F29/30, F31/33 or F34/35 induced accumulation of nitrite in culture medium indicating induction of NO production. Taken together these results show that TAE and fractionated alkaloids from $P$. juliflora act directly on glial cells, inducing activation and/or cytotoxicity, stimulating NO production, and may have an impact on neuronal damages observed on intoxicated animals.
\end{abstract}

(C) 2006 Elsevier Ltd. All rights reserved.

Keywords: Prosopis juliflora; Alkaloids; Astrocytes; Microglia; GFAP; Nitric oxide

*Corresponding author. Tel.: + 5571 32458602; fax: + 557132458917.

E-mail address: costasl@ufba.br (S.L. Costa). 


\section{Introduction}

Prosopis juliflora is a shrub that grows abundantly in the Sind and Punjab, provinces of Pakistan (Nasir and Ali, 1972). This plant was introduced in the states of Pernambuco and Rio Grande do Norte, Northeast Brazil, in 1942 and 1948, respectively, with seeds from Peru and Sudan (SPA, 1989). Due to their palatability and nutritional value, pods of $P$. juliflora or its bran are largely used for feeding dairy and beef cattle with good nutritional and economic results (Silva, 1981). Products from this plant have also been used for human consumption in bread, biscuits, sweeties, syrup and liquors (Van Den Eynden et al., 2003).

Extracts of $P$. juliflora seeds and leaves have several in vitro pharmacological effects such as antibacterial (Aqeel et al., 1989; Ahmad et al., 1986; Kanthasamy et al., 1989; Cáceres et al., 1995; Al-Shakh-Hamed and Al-Jammas, 1999; Satish et al., 1999), antifungal (Ahmad et al., 1989a, b; Kanthasamy et al., 1989; Kaushik et al., 2002), and anti-inflammatory properties (Ahmad et al., 1989a, b). These properties have been attributed to piperidine alkaloids (Ahmad et al., 1986; Batatinha, 1997). Intoxication with $P$. juliflora has been reported in the USA (Dollahite and Anthony, 1957), Peru (Baca et al., 1967), and also in Brazil (Figueiredo et al., 1995). In the later, the illness is called "cara torta", and it was firstly described by Figueiredo et al. (1995). This disease is characterised by emaciation, neuromuscular alterations, including muscular atrophy of the masseter, and histologic lesions like spongiosis, gliosis, the loss of Nissl substance and fine vacuolation of the perikaryon of neurons from trigeminal motor nuclei. Intoxicated goats in similar experimental conditions also presented lesions in the central nervous system (Tabosa, 2000), and the neurotoxic alterations observed in these animals were accompanied by glial reactivity, known as gliose (Tabosa, 2000; Tabosa et al., 2000).

Glial cells, mainly astrocytes, are essential to the development, homeostasis and detoxification in the CNS (Tardy, 2002; Mercier et al., 2003; Sutor and Hagerty, 2005). Moreover, these cells are known for their role on energetic support and immune response in the CNS against chemical, infectious or traumatic challenges (Aschner, 1998; Aloisi et al., 2000). The astrocyte reactivity, also known as astrogliose, happens as a response to physical damages or to exposure to toxic substances and in some forms of neurodegenerative diseases in the
CNS (Norton et al., 1992; Little and O'Callaghan, 2001). Astrogliosis is characterised by hyperplasy, hypertrophy, and accumulation of the specific component of the intermediate filaments, the glial fibrilary acidic protein (GFAP, Cookson and Pentreath, 1994; Gomes et al., 1999).

In this work, the effects of total alkaloidal extract (TAE) and its chromatographic fractions, obtained from $P$. juliflora leaves, on rat purified astrocyte primary cultures were studied, evaluating cell viability and reactivity, morphological changes, protein assay and nitric oxide (NO) production.

\section{Materials and methods}

\subsection{Leaves extract and extraction of alkaloids}

Leaves of $P$. juliflora were harvested at Salvador (BA) in the experimental fields of the Federal University of Bahia (UFBA). The alkaloid extract was obtained by an acid/basic modified extraction as described by Ott-Longoni et al. (1980), with minor modifications (Hughes et al., 2005). $P$. Juliflora leaves were dried in a greenhouse at $50{ }^{\circ} \mathrm{C}$, and the air-dried plant material $(874 \mathrm{~g})$ was extracted three times with hexane $(2.01 / \mathrm{kg})$ for $48 \mathrm{~h}$ at room temperature with occasional shaking to eliminate apolar constituents. The extract was then filtered and the residue was flooded with methanol $(1.51 / \mathrm{kg})$ using the above process. The methanol extract was concentrated in a rotary evaporation system at $40{ }^{\circ} \mathrm{C}$, and this concentrated residue was stirred with $0.2 \mathrm{~N} \mathrm{HCl}$ for $16 \mathrm{~h}$ followed by filtration. The solution was shaken with chloroform to remove the non-basic material. The aqueous layer was basified with ammonium hydroxide until it reached $\mathrm{pH} \mathrm{11,} \mathrm{and} \mathrm{then} \mathrm{was} \mathrm{extracted} \mathrm{with}$ chloroform. The chloroform phase was evaporated leading to the production of the TAE. This extract was fractionated by chromatography in a silica gel column using chloroform/methanol (99:1 to 1:1) as a solvent system with a subsequent $100 \%$ methanol elution. Thirty six fractions were obtained from the TAE, and after thin layer silica gel chromatography, they were developed with iodine and tested for the presence of alkaloids by the Dragendorf's test (Wagner et al., 1983). Alkaloid fractions (AFs) with the same chromatography profile were assembled and designated F21/22/23, F25/26, F27, F29/30, F31/33, F32 (which crystallized) and F34/35. The TAE and AFs were dissolved in dimethylsulfoxide (DMSO, Sigma, St Louis, MO) 
at a final concentration of $30 \mathrm{mg} / \mathrm{ml}$, and stored in the dark at $-20{ }^{\circ} \mathrm{C}$.

\subsection{Cell culture and treatments}

One-day-old postnatal Wistar rats used in this study were obtained from the Department of Physiology of the Health Sciences Institute of the Federal University of Bahia (Salvador, BA, Brazil). Astrocyte cultures were prepared according to Cookson and Pentreath (1994). Briefly, cerebral hemispheres of newborn Wistar rat pups were isolated aseptically and meninges were removed. The cortex was dissected out and then gently forced through a sterile $75 \mu \mathrm{m}$ Nitex mesh. Cells were suspended in Dulbecco's modified Eagle's medium (DMEM, Cultilab, SP, Brazil), supplemented with $6.25 \mu \mathrm{g} / \mathrm{ml}$ gentamicin, $2 \mathrm{mM}$ L-glutamine, $0.011 \mathrm{~g} / 1$ pyruvate, and $10 \%$ foetal calf serum (Cultilab, SP, Brazil) in a humidified atmosphere with $5 \% \mathrm{CO}_{2}$ at $37^{\circ} \mathrm{C}$. Astrocyte primary cultures yielded at least more than $95 \%$ purity, as confirmed by labelling with antibodies for the astrocyte marker, glial fibrillary acid protein (GFAP).

\subsection{Cell treatments}

Cells were treated with TAE or with AFs at final concentrations ranging between 0.3 and $30 \mu \mathrm{g} / \mathrm{ml}$, for $24 \mathrm{~h}$. The control group was treated with DMSO diluted in the culture medium at equivalent volume used in each treated group $(0.1 \%$ DMSO).

\subsection{Cytotoxicity and cell membrane integrity assays}

The TAE and AFs were tested for their cytotoxicity towards astrocytes using the 3-(4,5-dimethylthiazol-2-yl)-2,5-diphenyltetrazolium bromide (MTT; Sigma, St Louis, MO) test. The experiment was performed in 96 well plates (TPP Switzerland) $\left(1.6 \times 10^{4}\right.$ cells/plate $)$ after cells had become confluent $(95 \%)$. The cell viability was quantified by the conversion of yellow MTT by mitochondrial dehydrogenases of living cells to purple MTT formazan (Hansen et al., 1989). After the treatment, cells were incubated with MTT at a final concentration of $1 \mathrm{mg} / \mathrm{ml}$ for $2 \mathrm{~h}$. Thereafter, cells were lysed with $20 \%(\mathrm{w} / \mathrm{v})$ sodium duodecil sulphate, $50 \%(\mathrm{v} / \mathrm{v})$ dimethylformamide $(\mathrm{pH} 4.7)$, and plates were kept overnight at $37^{\circ} \mathrm{C}$ in order to dissolve formazan crystals. The optical density of each sample was measured at $492 \mathrm{~nm}$ using a spectrophotometer (Bio-Rad 550PLUS). Three independent experiments were carried out with four replicate wells for each analysis. Results from MTT test were expressed as percentages of the viability of the treated groups related to the control groups. A nonlinear regression was performed, using Graphpad Software Prism 3.0, to fit concentration-response curves and to calculate the $\mathrm{EC}_{50}$ of TAE and of the fractions F29/30, F31/33, F32 and F34/35, which were effective concentrations that killed $50 \%$ of cells.

Membrane integrity was evaluated by measuring the LDH activity on the culture medium of control and treated cells. After $24 \mathrm{~h}$ treatment, the culture medium was removed and the LDH activity was measured following the manufacturer's protocol (Doles, Goiás, Brazil).

\subsection{Morphological changes and glial cells reactivity}

Morphological changes and cell activation were studied analyzing the Rosenfeld's staining and by the immunocytochemistry patterns for the proteins GFAP (for astrocytes) and OX-42 (for microglial cells). The reactivity of glial cells induced by alkaloids from $P$. juliflora was also evaluated by the nitrate assay in the culture medium, which reflects nitric oxide production. Cells were treated for $24 \mathrm{~h}$ with 3 and $30 \mu \mathrm{g} / \mathrm{ml}$ TAE or cytotoxic fractions. Control cells were treated for $24 \mathrm{~h}$ with the same volume of DMSO that was used as a vehicle for TAE and fractions. DMSO $(0.1 \%)$ did not show any significant effect in the analyzed parameters, when compared with cultures that were not exposed to this solvent.

\subsection{Rosenfeld's staining and immunocytochemistry}

All control and treated glial cells seeded on polystyrene culture dishes of $40 \mathrm{~mm}$ in diameter (TPP, Switzerland) were rinsed three times with PBS without $\mathrm{Ca}^{2+}$ and $\mathrm{Mg}^{2+}$ and fixed for $10 \mathrm{~min}$ with methanol at $-20{ }^{\circ} \mathrm{C}$. Fixed cells were stained by the protocol established by Rosenfeld (Rosenfeld, 1947). The Rosenfeld's reagent $(1 \mathrm{ml})$ was added and incubated for $20 \mathrm{~min}$ at room temperature. Thereafter, the plates were rinsed with water, airdried, analyzed and photographed in an optic phase microscope (Nikon TS-100) using a digital camera (Nikon E-4300).

Astrocytes marker was achieved by immunocytochemistry for GFAP. Fixed cells were incubated 
under slow agitation with rabbit polyclonal antiGFAP (1/500, DAKO, Denmark) overnight and then with tetramethylrhodamine isothiocyanate conjugated goat anti-rabbit IgG antibody (1/250, Sigma, St Louis, MO) for $30 \mathrm{~min}$ at room temperature. Chromatin integrity or nuclear fragmentation/ condensation was investigated co-staining nuclear chromatin of fixed cells with the fluorescent dye Hoechst 33258 (Sigma, St Louis, MO), at a final concentration of $5 \mu \mathrm{g} / \mathrm{ml}$ in PBS, for $10 \mathrm{~min}$ at room temperature in a dark chamber. Thereafter, cells were analyzed by fluorescent microscopy (Olympus BX70) and photographed.

Microglial cell marking was achieved by immunocytochemistry against OX-42. Firstly, the endogenous peroxidase activity was blocked for $10 \mathrm{~min}$ with $3 \%$ hydrogen peroxide. The cells were incubated for $1 \mathrm{~h}$ with the mouse monoclonal anti-OX 42 (CD11b/c) antibody (1:200, CALTAG, Burlingame, CA). After that, cells were incubated with goat anti-mouse IgG peroxidase conjugated antibody (1:1000, Sigma) for $1 \mathrm{~h}$. Microglial cells were labelled brown after incubation with the substrate $0.3 \%$ 4-Cl-alpha naphtol/methanol solution diluted in PBS buffer (1:5) plus $\mathrm{H}_{2} \mathrm{O}_{2}(0.33 \mu \mathrm{l} / \mathrm{ml})$ at RT for $30 \mathrm{~min}$. To identify microglia, a Rosenfeld's costaining was performed. These cells were analysed and photographed in a light optic phase microscope using a digital camera. The number of immunoreactive cells was counted under the microscope using a $20 \times$ magnification in a $0.29 \mathrm{~mm}^{2}$ field. Always, 10 randomized representative fields were analyzed, and the proportion of OX-42 positive cells was presented as percentage of labelled cells related to the total number of cells counted.

\subsection{Western blot}

GFAP expression was also investigated by western immunoblot. Proteins were extracted after TAE or AFs exposure. Cells were rinsed twice with PBS, lysed and harvested in a $2 \%(\mathrm{w} / \mathrm{v})$ SDS, $2 \mathrm{mM}$ ethylene glycol-bis[ $\beta$-aminoethyl ether]- $N, N, N^{\prime} N^{\prime}-$ tetraacetic acid (EGTA), $4 \mathrm{M}$ Urea, $0.5 \%(\mathrm{v} / \mathrm{v})$ Triton X-100, 62.5 mM Tris-HCl buffer ( $\mathrm{pH} 6.8$ ), supplemented with $1 \mu \mathrm{l} / \mathrm{ml}$ of a cocktail of proteases inhibitors (Sigma, St Louis, MO). Protein content was determined by the method of Lowry et al. (1951), using a protein assay reagent kit (Bio-Rad, Hercules, CA). For analysis, $10 \mu \mathrm{g}$ protein was loaded onto a discontinuous $4 \%$ stacking and $8 \%$ running SDS polyacrilamide gel (SDS-PAGE).
Electrophoresis was performed at $200 \mathrm{~V}$ for $45 \mathrm{~min}$. Proteins were then transferred to a polyvinylidene fluoride membrane (PVDF, Bio-Rad, Hercules, CA, USA), at $100 \mathrm{~V}$ for $1 \mathrm{~h}$. Equal protein loading was confirmed by staining the membranes with Ponceau Red (Sigma). Thereafter, membranes were blocked for $1 \mathrm{~h}$ at room temperature in $20 \mathrm{mM}$ Tris-buffered saline $(\mathrm{pH} 7.5)$, containing $0.05 \%$ Tween 20 (TBS-T) and 1\% powdered skim milk. Subsequently, membranes were incubated with rabbit anti-GFAP (1:10000, Boehringer, Mannheim). Conjugated alkaline phosphatase goat anti-rabbit IgG or goat anti-mouse IgG (1/5000, Bio-Rad, Hercules, CA), were used as secondary antibodies. Immunoreactive bands were visualized using AP conjugated substrate Kit (Bio-Rad, Hercules, CA) according to manufacturer's instructions. Quantification was obtained by scanning densitometry (ScanJet 4C-HP) and analyzed using ImageJ 1.33u (Wayne Rasband, National Institute of Helth, USA). Antibody specificity and linearity of the densitometric analysis system were assessed by serial dilutions of total protein from cells in control conditions within a range of 5-20 $\mu \mathrm{g}$ of protein per lane.

\subsection{Nitrite assay}

The production of NO was assessed as nitrite accumulation in the culture medium by using a colorimetric test based on Griess reagent (Wang et al., 2002). Samples $(50 \mu 1)$ were collected after $24 \mathrm{~h}$ of treatment. Equal volumes of culture supernatant and Griess reagent ( $1 \%$ sulfanilamide, $0.1 \% \mathrm{~N}-(1-$ naphthyl) ethylene diamine dihydrochloride, $2 \%$ phosphoric acid) were mixed. The mixture was incubated for $10 \mathrm{~min}$ at room temperature, and the absorbance at $560 \mathrm{~nm}$ was measured on a microplate reader (Thermo Plate TP-Reader). The concentrations of nitrite in the samples were determined based on a sodium nitrite standard curve $\left(\mathrm{NaNO}_{2}\right.$, $1.26-100 \mathrm{mmol} / 1)$.

\subsection{Statistical analysis}

Results are expressed as mean \pm standard deviation. One way ANOVA followed by the StudentNewmann-Keuls test was used to determine the statistical differences among groups differing in only one parameter. Student's $t$-test was used to compare two groups. Values of $P<0.05$ were considered as significant. 


\section{Results}

\subsection{MTT test and LDH activity}

The effects of TAE and alkaloidal fractions from $P$. juliflora leaves upon the cell viability were assessed by measuring the mitochondrial function using the MTT test, which measures the reduction of the tetrazolium salt (MTT) to the purple formazan by cellular dehydrogenase enzymes on living cells (Fig. 1(A)). The fractions F21/22/23 and $\mathrm{F} 27$, at any concentration adopted $(0.03-30 \mu \mathrm{g} / \mathrm{ml})$, do not induced any significant alterations on the levels of MTT conversion in astrocyte primary cultures when compared with control cultures (0.001-0.1\% DMSO). On the other hand, $24 \mathrm{~h}$

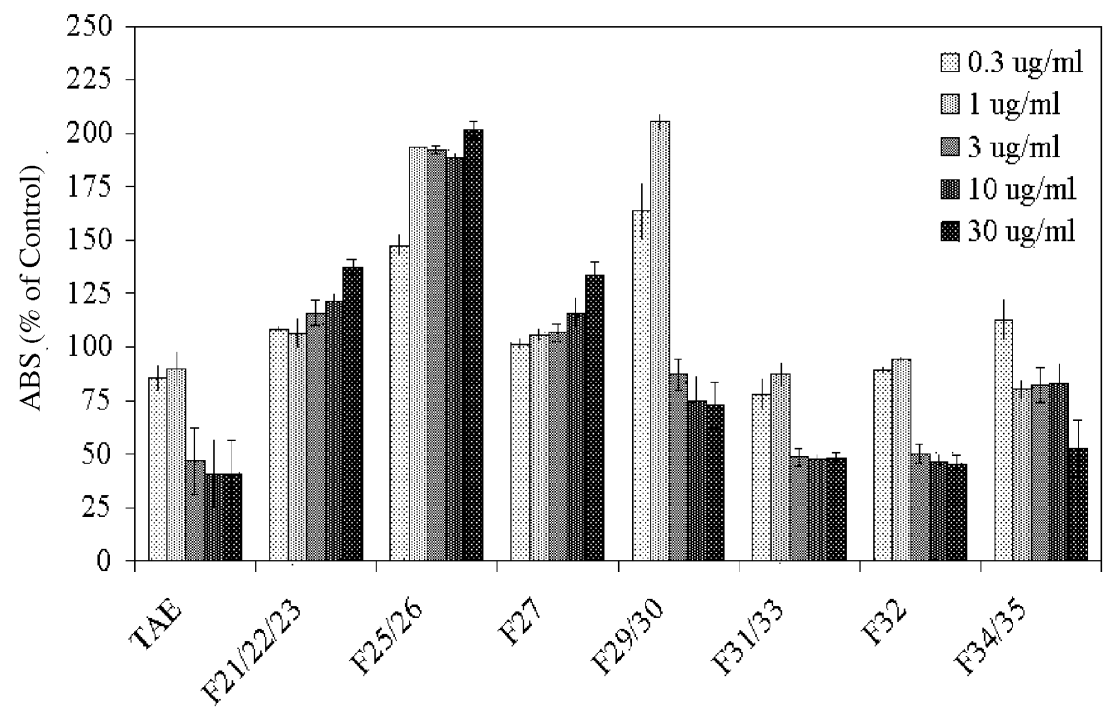

(A)

Treatment

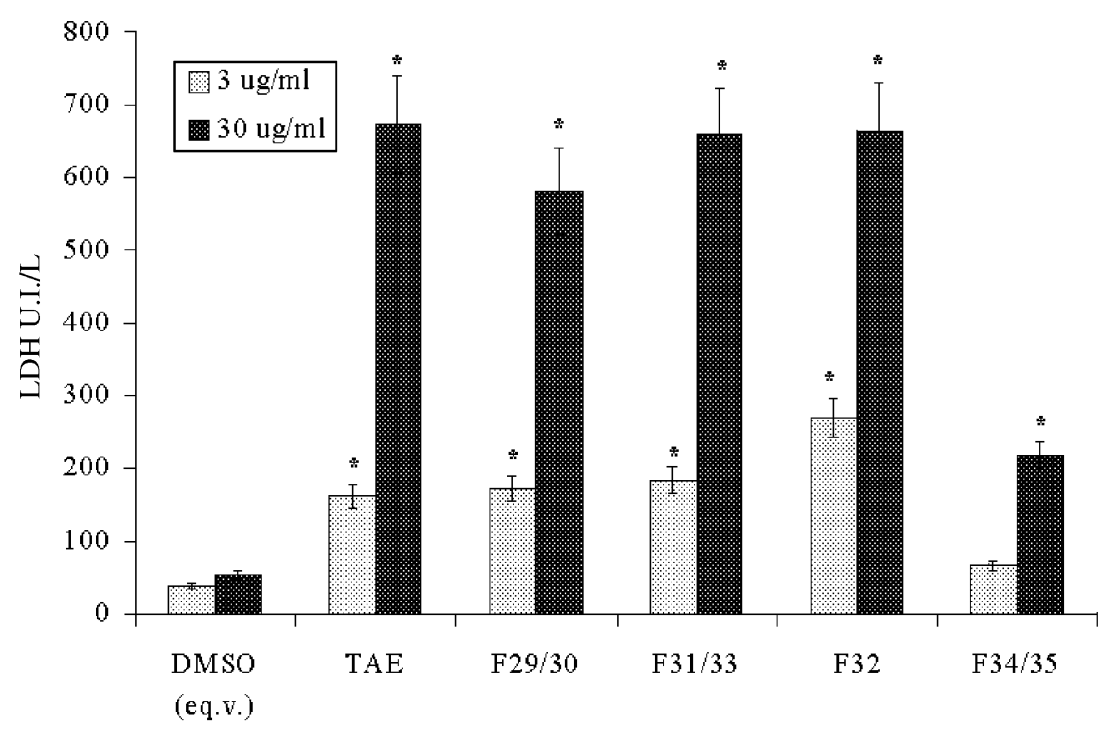

(B)

Treatment

Fig. 1. Cytotoxicity assay on astrocyte primary cultures treated for $24 \mathrm{~h}$ with the equivalent volume of the vehicle of dilution (DMSO) or with the TAE, extracted from $P$. juliflora leaves, or its fractions. (A) MTT test of cells exposed to DMSO $(0.001-0.1 \%)$ or $0.3-30 \mu \mathrm{g} / \mathrm{ml}$ TAE, F21/22/23, F25/26, F27, F29/30, F31/33, F32 and F34/35. (B) LDH activity on the culture medium of cells exposed to DMSO $(0.01-0.1 \%)$, or $3-30 \mu \mathrm{g} / \mathrm{ml} \mathrm{TAE}, \mathrm{F} 29 / 30, \mathrm{~F} 31 / 33$, F32 or F34/35; values for vehicle control samples were set at $100 \%$; $* P<0.05 \%$. 
exposure to $0.03-30 \mu \mathrm{g} / \mathrm{ml} \mathrm{F25/26}$ induced a significant increase $(P<0.001)$ on the levels of MTT conversion on astrocytes primary cultures, indicating an increased cellular metabolic activity. The same effect was observed when cells were exposed to $0.1-0.3 \mu \mathrm{g} / \mathrm{ml} \mathrm{F} 29 / 30$, but it was not possible to determine the $\mathrm{IC}_{50}$ for this alkaloidal fraction in the experimental condition adopted. Moreover, we observed that TAE, F29/30, F31/33, F32 and F34/35 reduced significantly $(P<0.001)$ the MTT conversion in a dose-dependent manner but with different potencies. The median inhibitory concentrations $\left(\mathrm{EC}_{50}\right.$ values) were $2.87 \mu \mathrm{g} / \mathrm{ml}$ (TAE), $2.82 \mu \mathrm{g} / \mathrm{ml}$ (F31/33), $3.01 \mu \mathrm{g} / \mathrm{ml}$ (F32) and $30 \mu \mathrm{g} / \mathrm{ml}$ (F27). The results from the $\mathrm{EC}_{50}$ determination for F29/30 and F34/35 were not significant coefficients of correlation $\left(R^{2}<0.95\right)$.

The measure of lactate dehydrogenase $(\mathrm{LDH})$ on the culture medium of cells exposed to $3-30 \mu \mathrm{g} / \mathrm{ml}$ of TAE and of the main cytotoxic fractions (F29/30, $\mathrm{F} 31 / 33, \mathrm{~F} 32$ and $\mathrm{F} 34 / 35$ ) revealed that they induced a dose-dependant membrane damage (Fig. 1(B)). Compared with the controls (0.01-0.1\% DMSO), a significant $(P<0.01)$ increase of 4.2 to 6.9 times was observed on the LDH activity in the culture medium of cells exposed to $3 \mu \mathrm{g} / \mathrm{ml}$ TAE, F29/30, F31/33. This effect was also evident, but in less significant extension, in cells treated with $3 \mu \mathrm{g} / \mathrm{ml} \mathrm{F} 34 / 35$ (1.7 times). When cells were exposed to $30 \mu \mathrm{g} / \mathrm{ml} \mathrm{TAE}$ and cytotoxic fractions the levels of LDH activity in the culture medium increased 4.1 times for the F34/35, the less cytotoxic fraction, and 11.1-12.8 times for the TAE and F29/30, F31/33, and F32 fractions.

The exposition of the primary cultures during $24 \mathrm{~h}$ with the dilution vehicle DMSO in equivalent volume to the adopted concentrations did not showed any significant alteration in the analyzed parameters, when compared with cultures that were not exposed to this solvent.

\subsection{Morphological changes induced by TAE and alkaloidal fractions}

The morphology and immunostaining patterns of cells treated with DMSO $(0.001-0.1 \%)$ or with TAE and AFs $(0.3-30 \mu \mathrm{g} / \mathrm{ml})$ for $24 \mathrm{~h}$ are shown in Figs. 2-5. The majority of astrocytes in control conditions $(0.001-0.1 \%$ DMSO) presented a flat/ polygonal or bipolar fibroblast-like phenotype (Figs. 2(A)-(C)). On the other hand, the exposure to $3-30 \mu \mathrm{g} / \mathrm{ml} \mathrm{TAE}, \mathrm{F} 29 / 30, \mathrm{~F} 31 / 33$, F32, or F34/35 for $24 \mathrm{~h}$ the induced structural changes on astrocytes in a dose dependent manner. The majority of cells exposed to the lowest TAE, F29/30, F31/33 and F34/35 concentration $(0.3 \mu \mathrm{g} / \mathrm{ml})$ presented discrete cellular changes, some of them presenting a cell body retraction and stellate morphology (Fig. 2(D), (G), (J), (M) and (P)). Cells exposed to $3 \mu \mathrm{g} / \mathrm{ml} \mathrm{TAE}$, F29/30, F31/33, F32, or F34/35 clearly retracted their cell bodies becoming shorter, thicker and more stellate than control ones (Figs. 2(E), (H), (K), (N) and (Q)). Astrocytes exposed to $30 \mu \mathrm{g} / \mathrm{ml}$ of TAE, $\mathrm{F} 29 / 30, \mathrm{~F} 31 / 33$, or F34/35 presented nuclear and cytoplasmic condensation (Fig. 2(F), (I), (L) and $(\mathrm{R})$ ). The fraction F32 was very cytotoxic to astrocytes at the highest concentration $(30 \mu \mathrm{g} / \mathrm{ml})$. The remaining adherent cells were completely disrupted (Fig. 2(O)).

Few microglial cells immunostained for OX-42 appears as black small round cells on astrocyte primary cultures in control conditions $(<5 \%)$ (Fig. 3(A)). Exposure to $30 \mu \mathrm{g} / \mathrm{ml}$ TAE increased the proportion of OX-42 positive microglial cells, possibly indicating their activation. The proportion of OX-42 positive cells in control conditions (0.01-0.1\% DMSO) was around $1.3 \%$. The proportion of OX-42 positive cells in cultures treated with $30 \mu \mathrm{g} / \mathrm{ml}$ TAE was around $28.7 \%$ (Fig. 3(B)). This effect was also evident in cultures exposed to $30 \mu \mathrm{g} /$ $\mathrm{ml} \mathrm{F} 29 / 30$, F31/33, or F32, which presented $17.4 \%$, $19.0 \%$ and $7.3 \%$ of OX-42 positive cells, respectively (Fig. 3(B)).

Astrocytes immunostained for GFAP in control conditions (0.01-0.1\% DMSO) presented a monolayer of large flat cells with a star-like shape (Fig. 4(A)). However, exposure of cells to an intermediary concentration $(3 \mu \mathrm{g} / \mathrm{ml})$ of TAE or AFs induced significant changes on the pattern of GFAP expression and immunostaining. The majority of astrocytes treated with $3 \mu \mathrm{g} / \mathrm{ml}$ TAE presented many GFAP positive processes (Fig. 4(B)). The same was also evident, but in a lesser extension, in astrocytes exposed to $3 \mu \mathrm{g} / \mathrm{ml} \mathrm{F29/30} \mathrm{(Fig.} \mathrm{4(C))} \mathrm{or} 3 \mu \mathrm{g} / \mathrm{ml}$ F31/33 (Fig. 4(D)). On the other hand, astrocytes exposed to $3 \mu \mathrm{g} / \mathrm{ml} \mathrm{F} 32$ or $3 \mu \mathrm{g} / \mathrm{ml} \mathrm{F} 34 / 35$ showed a very heterogeneous GFAP expression (Fig. 4(E) and (F)). Astrocytes exposed to $30 \mu \mathrm{g} / \mathrm{ml}$ TAE, F29/30, F31/33, F32 or F34/35 were completely disrupted (data not shown). Moreover, the Hoechst-33258 staining also revealed that at this highest concentration $(30 \mu \mathrm{g} / \mathrm{ml})$, TAE, F29/30, F31/33, or F34/35 induced a condensation of the chromatin nuclear in the majority of cells (Figs. 5(D), (F) and (J), respectively). This effect was observed on the 

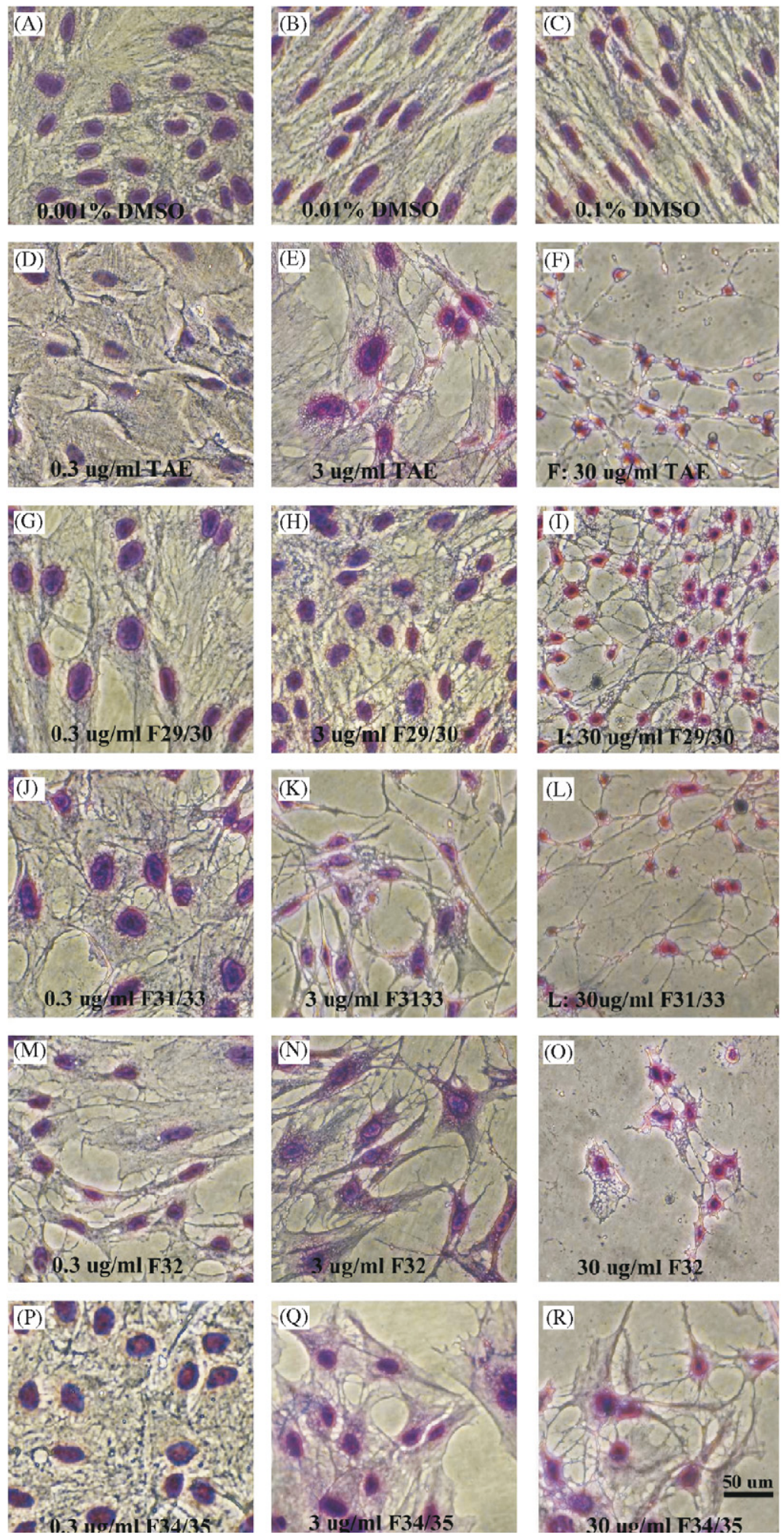

Fig. 2. Photomicrograph of astrocyte primary cultures in control (DMSO $0.01-0.1 \%$ ) or exposed for $24 \mathrm{~h}$ to $0.3-303 \mu \mathrm{g} / \mathrm{ml} \mathrm{TAE}$, F29/30, F31/33, F32 or F34/35 h, and staining by Rosenfeld's staining. Obj. $20 \times 0.70$, Scale bars $=100 \mu \mathrm{m}$. 
(A)
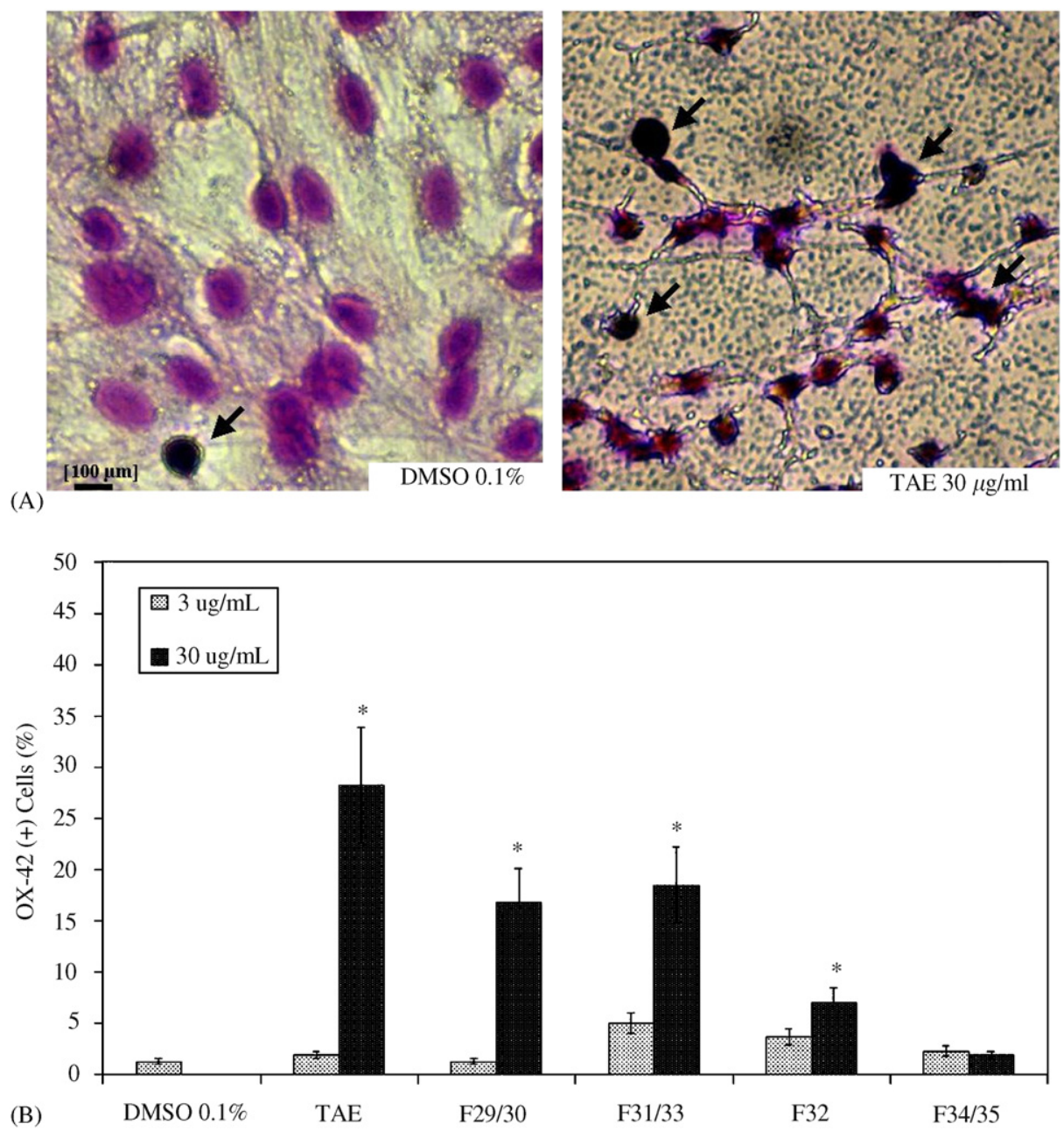

Fig. 3. Rosenfeld's staining and immunocytochemistry for the microglial protein OX-42, on astrocyte primary cultures (detail). (A) Photomicrography of OX-42 positive round microglial cells (arrows) in control conditions (DMSO $0.1 \%$ ) or treated for $24 \mathrm{~h}$ with $30 \mu \mathrm{g} / \mathrm{ml}$ TAE. Obj. $20 \times 0.70$. Scale bars $=50 \mu \mathrm{m}$. (B) Quantification of positive cells OX-42 in control conditions (DMSO $0.01-0.1 \%$ ) or treated with $3-30 \mu \mathrm{g} / \mathrm{ml}$ of ETA, F29/30, F31/33, F32 and F35/36; $* P<0.05$.

totality of the remaining adherent cells exposed to $30 \mu \mathrm{g} / \mathrm{ml} \mathrm{F32} \mathrm{(Fig.} \mathrm{5(H)).} \mathrm{GFAP} \mathrm{expression} \mathrm{was}$ also examined by Western immunoblot $24 \mathrm{~h}$ posttreatment (Figs. 6(A) and (B)). GFAP is seen as an immunoreactive band of $49 \mathrm{kDa}$ protein. Astrocytes treated with $3 \mu \mathrm{g} / \mathrm{ml}$ TAE over expressed GFAP compared to control ones. No significant changes were detected on GFAP expression in astrocytes exposed to $3 \mu \mathrm{g} / \mathrm{ml} \mathrm{F29/30,} \mathrm{F31/33,} \mathrm{F32} \mathrm{or} \mathrm{F34/35.}$

\subsection{Effect of alkaloids from P. juliflora on $N O$ production}

In control conditions, the medium of primary astrocytes cultures presented very low levels of nitrite: $4.05 \pm 0.56$ and $5.87 \pm 0.46 \mathrm{pg} / \mathrm{ml}$ for cultures treated with $0.01-0.1 \%$ DMSO, respectively (Fig. 7). No significant changes on nitrite levels were observed on the culture medium of astrocytes exposed to $3 \mu \mathrm{g} / \mathrm{ml}$ TAE, F29/30 or F31/33. However, $24 \mathrm{~h}$ treatment of the astrocytes with $3 \mu \mathrm{g} / \mathrm{ml}$ F32 or $\mathrm{F} 34 / 35$ induced a significant $(P<0.001)$ increase on nitrite production, with values reaching $19.25 \pm 1.94 \mathrm{pg} / \mathrm{ml}$ and $11.35 \pm 1.73 \mathrm{pg} / \mathrm{ml}$. Moreover, incubation with $30 \mu \mathrm{g} / \mathrm{ml}$ TAE for $24 \mathrm{~h}$ induced a significant accumulation $(P<0.001)$ of nitrite on the culture medium, with values reaching $15.08 \pm 1.41 \mu \mathrm{M}$, and also a slight but significant increase $(P<0.05)$ on nitrite levels on the medium of astrocyte cultures treated with $30 \mu \mathrm{g} / \mathrm{ml} \mathrm{F29/30,}$ $\mathrm{F} 31 / 33$ or $\mathrm{F} 32$, with values reaching $10.33 \pm 1.21$, $9.91 \pm 0.94$, and $14.05 \pm 1.55 \mathrm{pg} / \mathrm{ml}$, respectively. 

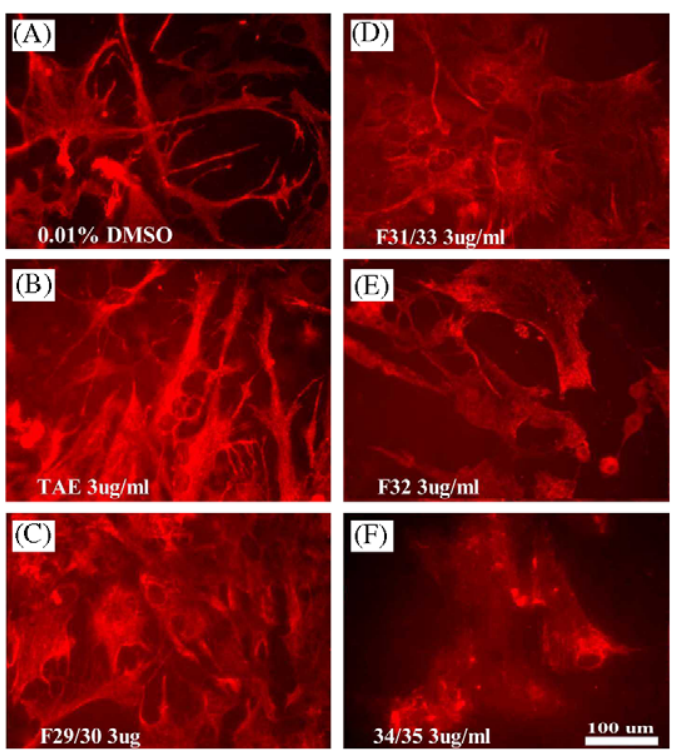

Fig. 4. GFAP immunocytochemistry, of astrocyte primary cultures $24 \mathrm{~h}$ post-treatment. Cells were treated with the vehicle $0.1 \%$ DMSO (A), or $3 \mu \mathrm{g} / \mathrm{ml}$ TAE (B), F29/30 (C), F31/33 (D), F32 (E), or F34/35 (F). Obj. $\times 20$. Scale bars $=100 \mu \mathrm{m}$.

\section{Discussion}

Primary cultures of cortical astrocytes from rats have been cultivated during 21 days and then exposed to different concentrations of TAE or of its fractions. Their effects were investigated on cell viability and reactivity. As determined by immunocytochemistry for the protein GFAP, these cultures presented about $95 \%$ of GFAP-labelled astrocytes, and about $1.3 \%$ of microglia cells (OX-42 positive). The biological activity of alkaloids extracted from pods of $P$. juliflora was measured in order to test the possible direct effect of these, on astrocytes and the potential connection with the neurotoxic phenomena observed by Figueiredo et al. (1995) and Tabosa et al. $(2000,2002)$ in early animal studies. Astroglial primary cultures were exposed to $0.3-30 \mu \mathrm{g} / \mathrm{ml} \mathrm{TAE}$ or alkaloidal fractions, and their effects on cell viability and reactivity were investigated. The cleavage of tetrazolium ring in MTT involves the mitochondrial succinate dehydrogenase and depends on the activity of the respiratory chain and the redox-state of the mitochondria (Mosman 1983; Shearman et al., 1995) responsible for the production of cell energy. In a short exposure TAE and its fractions (F29/30, F31/33, F32 and F34/35) induced a significant reduction in the conversion of MTT, which means a cellular disintegration and cytotoxicity. We observed in parallel, a dose-dependant
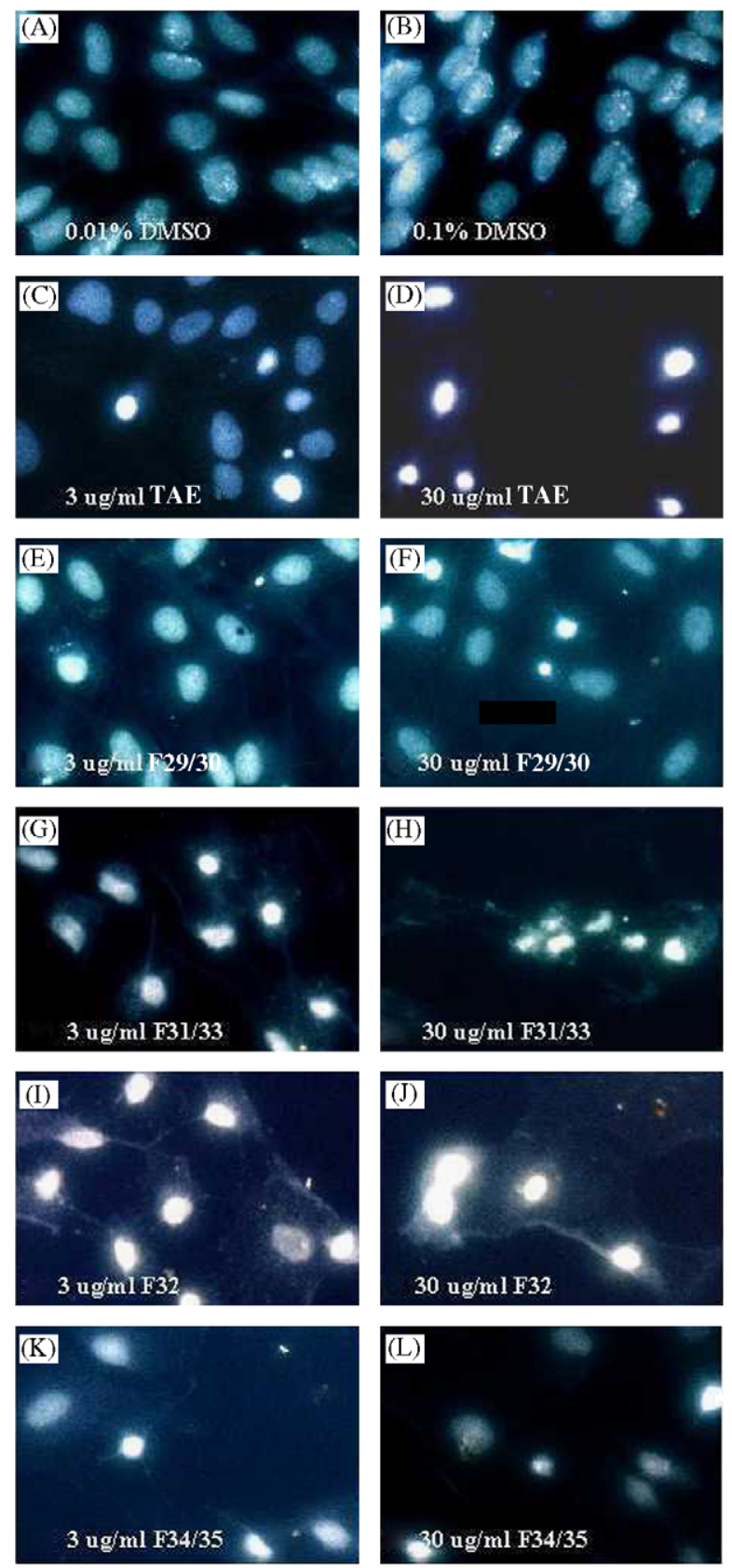

Fig. 5. Hoechst-33258 staining of nuclear chromatin of astrocyte primary cultures $24 \mathrm{~h}$ post-treatment. Cells were treated with the vehicle $0.01-0.1 \%$ DMSO ((A), and (B)), or 3-30 $\mathrm{g} / \mathrm{ml}$ TAE ((C), and (D), respectively), 3-30 $\mu \mathrm{g} / \mathrm{ml} \mathrm{F29/30} \mathrm{((E),} \mathrm{and} \mathrm{(F),}$

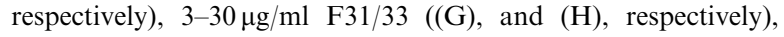
$3-30 \mu \mathrm{g} / \mathrm{ml} \mathrm{F32} \mathrm{((I),} \mathrm{and} \mathrm{(J),} \mathrm{respectively)} \mathrm{or} \mathrm{3-30} \mu \mathrm{g} / \mathrm{ml} \mathrm{F34/35}$ $(\mathrm{K})$, and (L), respectively). Obj. $\times 20$. Scale bars $=100 \mu \mathrm{m}$.

increase in the levels of LDH activity in the culture medium of cells treated with the TAE and the fractions, showing damages on plasmatic membrane. Such an effect was previously demonstrated 

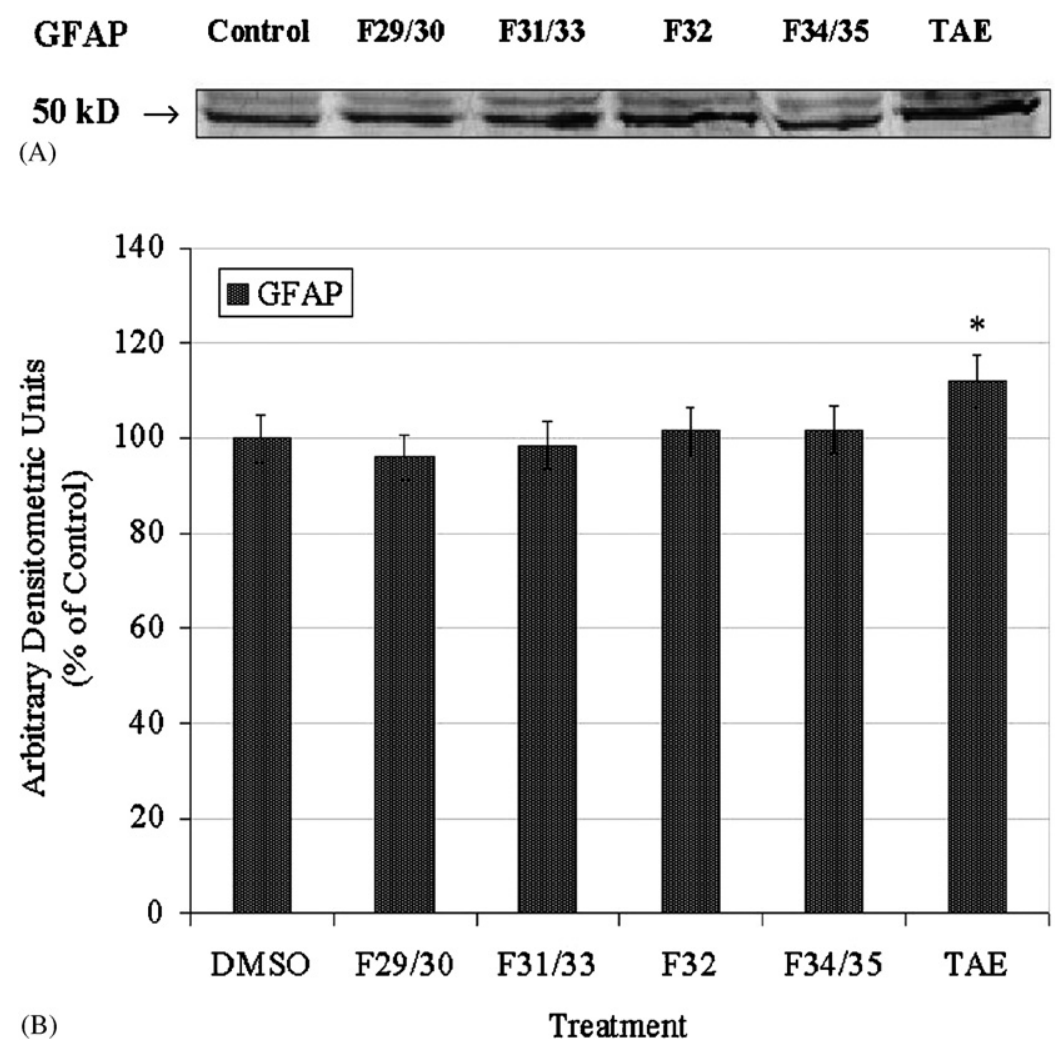

Fig. 6. Modulation of glial fibrilary acidic protein (GFAP) expression by alkaloids from $P$. juliflora in astrocyte primary cultures. (A) Western blotting analysis of GFAP protein expression in control conditions (0.01 DMSO), and treated with $3 \mu \mathrm{g} / \mathrm{ml} \mathrm{TAE}$, F29/30, F31/33, F32 or F34/35 for $24 \mathrm{~h}$. Samples containing $10 \mu \mathrm{g}$ of total protein were electrophoretically separated through $10 \%$ polyacrylamide gels containing $0.1 \%$ SDS in running buffer. (B) Histogram represents the relative expression of GFAP.

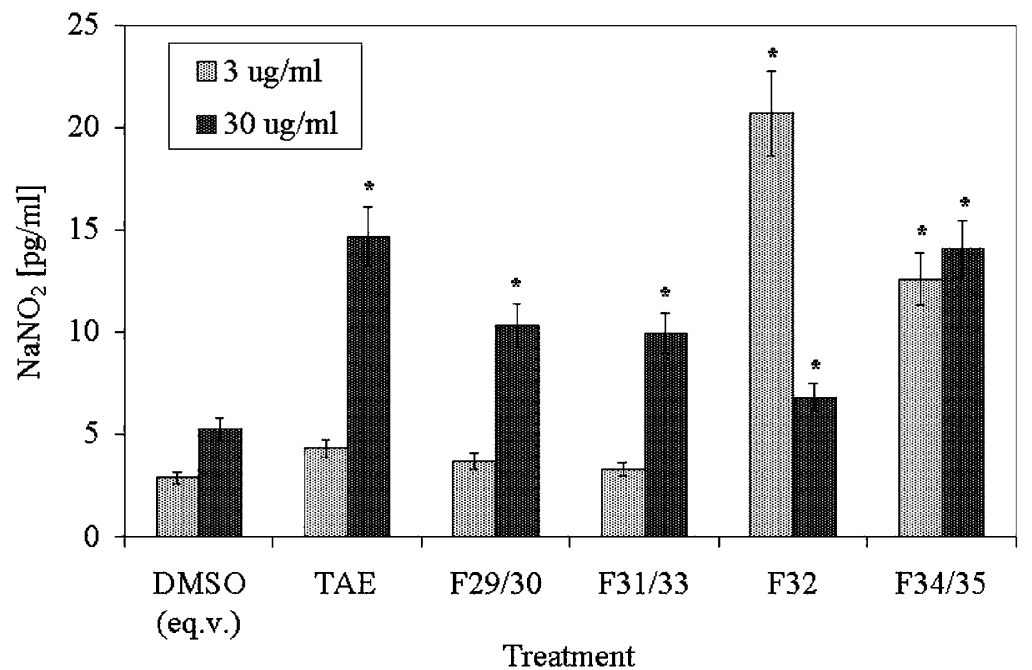

Fig. 7. Measure of $\mathrm{NaNO}_{2}$ on the culture medium of astrocyte primary cultures in control conditions (0.1-0.01 DMSO), and treated with 3-30 $\mu \mathrm{g} / \mathrm{ml} \mathrm{TAE}, \mathrm{F} 29 / 30, \mathrm{~F} 31 / 33$, F32 or F34/35, and evaluated at $24 \mathrm{~h}$ post-treatment. Values for vehicle control samples were set at $100 \%$; $* P<0.05$. 
on erythrocytes subjected to alkaloids from $P$. juliflora, provoking significant hemolysis at concentrations five-fold higher (Kandasamy et al., 1989). Moreover, the Rosenfeld's staining clearly evidenced that the cells exposed to the highest concentration used $(30 \mu \mathrm{g} / \mathrm{ml})$, of TAE, F29/30, F31/33, F32 and F34/35, showed a strong contraction of the cellular body and a condensation of the nuclear chromatin, which suggest a loss of cellular viability. Associated with these data, the analyses of the morphologic aspects of the cell nuclei with the intercalating Hoechst-33258, showed a condensation of the chromatin in these cells treated with $30 \mu \mathrm{g} / \mathrm{ml} \mathrm{TAE}$ and cytotoxic fractions, indicating that the cells were in the initial states of a programmed cell death.

One of the most important function of the astrocytes is the control of neurotoxins inside the CNS and this capacity is conferred by a variety of enzymatic systems (Coyle and Schwarcz, 2000). These cells possess the remarkable properties of responding to apparently all forms of neurological damage, including those induced by toxicants, undergoing activation, known as astrogliosis. Astrogliosis is associated with an altered phenotype due to up-regulation of a large number of molecules (Eddleston and Mucke 1993; Cookson and Pentreath 1994; Mead and Pentreath, 1998; Lefrancois et al., 1997; Costa et al., 2002), including the accumulation of intermediate filaments containing GFAP. Several studies have shown that GFAP is up-regulated after exposure to a various set of toxic chemicals that includes kainic acid, mercury chloride, aluminium chloride, toluene, ethanol, dibutyryl-cAMP and trimethyltin (Rataboul et al., 1989; Cookson and Pentreath, 1994; Mead and Pentreath, 1998; Harry et al., 2002). While the increase in the expression of the GFAP can be associated to astrogliosis, reaction to physical damages and even neurodegeneration (Tardy, 1991; Coyle and Schwarcz, 2000; Costa et al., 2002), the reduction of its expression can reflect abnormal synaptogenesis and neurotransmission (O'Callaghan, 1991; Rajkowska et al., 2002; Moises et al., 2002). In our study, it was demonstrated that the $24 \mathrm{~h}$ treatment of astrocytes with $3 \mu \mathrm{g} / \mathrm{ml}$ TAE modified their morphology and increased the expression of GFAP. The cells presented long multipolar processes. These data corroborate our previous studies, showing an increase of the GFAP immunostaining in astrocytes exposed to $3 \mu \mathrm{g} / \mathrm{ml}$ of a TAE from P. juliflora pods (Hughes, 2004; Hughes et al., 2004).
Although alterations in the levels of expression of the GFAP have not been evidenced in the astrocytes exposed to the alkaloidal fractions, by the imunocytochemical techniques, the same experimental conditions, showed significant changes in the morphology of the cells and particularly in the cells exposed to $3 \mu \mathrm{g} / \mathrm{ml} \mathrm{F} 32$, underlining the capacity of astrocytes to react to low levels of this fraction. On the other hand, a reduction in the GFAP protein level in cells treated with the highest concentrations of both TAE and tested fractions (data not shown), shows the appearance of a phenomenon of cytotoxicity in the astrocytes, and may have an impact on the functional and structural viability of the neurons in intoxicated animals.

Microglia, the resident immune cells of the brain, act in the same way as those of tissue macrophages in other organs, serving as tissue phagocytes (when required) and being the first line of defence against invading pathogens and other challenges (Dickson et al., 1993; Giulian et al., 1994; Streit et al., 1999; Gonzalez-Scarano and Baltuch, 1999). Activated microglia have been referred to turn into small round cells without processes, expressing OX-42 (Streit et al., 1988; Salimi and Humpel, 2002). Our results demonstrated clearly, by immunocytochemical methods, a significant increase in the ratio of positive OX-42 cells in the astrocyte primary cultures treated during $24 \mathrm{~h}$ with $30 \mu \mathrm{g} / \mathrm{ml} \mathrm{TAE}$ and cytotoxic fractions (F29/30, F31/33 and F32), showing that these compounds are also able to induce activation of the microglia (microgliose). When activated, these cells, may endanger the surviving and viability of neurons, according to the degree of their activation, and may involve them in the observed phenomena of neurotoxicity induced by $P$. juliflora in cattle and goats (Tabosa, 2000; Tabosa, 2002).

In the CNS of mammals, one of the lines of production of nitric oxide (NO) consist in generating a system of free radicals, absent in resting glial cells. It can however be induced, through by the conversion of L-arginine to L-citruline by the inducible nitric oxide synthase. Moreover, among several factors released by activated glia, NO seems to play a critical role in stress-induced brain damage (Gebicke-Haerter, 2001; Nicholson et al., 2004). The expression of this enzyme has been detected in culture of glial cells and astrocytes from neuropatologic samples (Manning et al., 2001). In this study, we observed a significant increase of the accumulation of nitrite, the stable form of the $\mathrm{NO}$, in the 
culture medium of cells treated with $3 \mu \mathrm{g} / \mathrm{ml} \mathrm{F32}$ and $\mathrm{F} 34 / 35$ or with $30 \mu \mathrm{g} / \mathrm{ml}$ TAE, F29/30, F31/33 and F34/35. These results suggest the involvement of NO in the induced phenomena of neurotoxicity provoked by alkaloids from $P$. juliflora, since this neuromediator can cause cytotoxicity in nervous cells (Manning et al., 2001).

According to Nakano et al. (2004a, b), the cytotoxicity of alkaloids from $P$. juliflora leaves and pods is correlated to the presence of an indolizidine ring in the centre of the molecule, and the positioning of specific functional groups at 3 and $3^{\prime}$ positions in the heterocyclic rings. We can suspect that alkaloids present in the TAE and cytotoxic fractions, and especially in F32, possess these two chemical characteristics, which however remain to be investigated. These alkaloids are amphoteric substances, comporting the polar heterocyclic and indol rings, and the apolar chains that join them. This double character regarding the polarity can be an element that promotes the disarrangement of the structure of the fluid mosaic of the plasmatic membranes of the astrocytes when these compounds are in high concentrations. Moreover, it was recently shown that the alkaloid juliflorine is a non-competitive acetylcholinesterase inhibitor and also presents a $\mathrm{Ca}^{2+}$-channel blocking activity, which should be involved in neuromuscular spasmsobserved in animals intoxicated by $P$. juliflora (Choudhary et al., 2005).

In conclusion, this study demonstrated that some alkaloids from $P$. juliflora leaves can act directly on glial cells, inducing either their activation, or cytotoxicity, with an apparent dose dependence.

Chromatographic analyses have disclosed that the F32 fraction can be a pure substance, and clearly, for the set of experiments carried through and its results, it was the most toxic fraction. Therefore, we can still suggest that among the active components, present in the $P$. juliflora TAE, the F32 fraction would be more effective in inducing cytotoxicity and reactivity in glial cells. The characterisation of its chemical structure will contribute to a better understanding of its mechanism of action in glial cells and of its impact on the viability of neurons associated with alkaloids from P. juliflora.

\section{Acknowledgements}

This work was supported in part by Grants from Fundação de Amparo à Pesquisa e Extensão do
Estado da Bahia (FAPESB), and Conselho Nacional de Desenvolvimento Científico e Tecnológico (CNPq). We gratefully acknowledge the research support provided by Mestrado em Ciências Veterinárias-UFBA, and the Fundação Coordenação de Aperfeiçoamento de Pessoal de Nível Superior (CAPES).

\section{References}

Ahmad, A., Ali Khan, K., Ahmad, V.U., Qazi, S., 1986. Antibacterial activity of juliflorine isolated from Prosopis juliflora. Planta Med. 1 (1), 285-288.

Ahmad, A., Khursheed, A.K., Sabiha, Q., Viqaruddin, A., 1989a. Antifungial activity of some hydrosoluble Prosopis juliflora alkaloids. Fitoterapia 60 (1), 86-89.

Ahmad, V.U., Sultana, A., Qazi, S., 1989b. Alkaloids from the leaves of Prosopis juliflora. J. Nat. Prod. 52 (3), 497-501.

Aloisi, F., Serafini, B., Adorini, L., 2000. Glia-T cell dialogue. J. Neuroimmunol. 107, 111-117.

Al-Shakh-Hamed, W.M.A., Al-Jammas, M.A., 1999. The antimicrobial activity of alkaloidal fraction of Prosopis juliflora. Iraqi J. Vet. Sci. 12 (2), 281-287.

Aqeel, A., Khursheed, A.K., Viqaruddin, A., Sabiha, Q., 1989. Antimicrobial activity of julifloricine isolated from Prosopis juliflora. Arzneim. Forsch./Drug Res. 39 (6), 652-655.

Aschner, M., 1998. Astrocytes as mediators of immune and inflammatory responses in the CNS. Neurotoxicology 19 (2), 269-282.

Baca, S.F., Vallenas, A., Novoa, C., 1967. Estudio experimental de la "Coquera" en caprinos. Revta Fac. Med. Vet. 18 (20), 131-159.

Batatinha, M.J.M., 1997. Untersuchungen über toxische Einflüsse von Prosopis juliflora Sw.D.C (Algarobeira) auf Zellkulturen sowie auf die Pansenfermentation beim Rind (in vitro) [Doctoral Thesis]. Hannover: Veterinary Medicine University.

Cáceres, A., Menéndez, H., Méndez, E., Cohobón, E., Samayoa, B.E., Jauregui, E., 1995. Antigonorrhoeal activity of plants used in Guatemala for the treatment of sexually transmitted diseases. J. Ethnopharm. 48, 85-88.

Choudhary, M.I., Nawaz, S.A., Zaheer-ul-Haq, A., Azim, M.K., Ghayur, M.N., Lodhi, M.A., Jalil, S., Khalid, A., Ahmed, A., Rode, B.M., Atta-ur-Rahman, Gilani, A.U., Ahmad, V.U., 2005. Juliflorine: a potent natural peripheral anionic-sitebinding inhibitor of acetylcholinesterase with calcium-channel blocking potential, a leading candidate for Alzheimer's disease therapy. Biochem. Biophys. Res. Commun. 332 (4), 1171-1179.

Cookson, M.R., Pentreath, V.W., 1994. Alterations in the glial fibrillary acidic protein content of primary astrocyte cultures for evaluation of glial cell toxicity. Toxic In vitro 8 (3), 351-359.

Costa, S.L., Planchenault, T., Charrière-Bertrand, C., Mouchel, Y., Fages, C., Juliano, S., et al., 2002. Astroglial permissivity for neurotic outgrowth in neuron-astrocyte cocultures depends on regulation of lamini bioavailability. Glia 37, 105-113.

Coyle, J.T., Schwarcz, R., 2000. Mind glue: implications of glial cell biology for psychiatry. Arch. Gen. Psych. 57 (1), 90-93. 
Dickson, D.W., Lee, S.C., Mattiace, L.A., Yen, S.H., Brosnan, C., 1993. Microglia and cytokines in neurological disease, with special reference to AIDS and Alzheimer's disease. Glia 7, 75-83.

Dollahite, J.W., Anthony, W.V., 1957. Malnutrition in cattle on an unbalanced diet of mesquite beans. Texas Agri. Exp. Station 11, 209-212.

Eddleston, M., Mucke, L., 1993. Molecular profile of reactive astrocytes: implication for their role in neurological disease. Neuroscience 54, 15-36.

Figueiredo, L.J.C., Ferreira, M.M., Távora, J.P.F., Dantas, J., Simões, S.D., 1995. Estudo clínico e anátomopatológico da doença "cara torta" em bovinos no nordeste brasileiro. Arq. Med. Vet.-UFBA 18 (1), 175-183.

Gebicke-Haerter, P.J., 2001. Microglia in neurodegeneration: molecular aspects. Microsc. Res. Tech. 54 (1), 47-58.

Giulian, D., Leara, J., Li, J., Keenen, C., 1994. Phagocytic microglia release cytokines and cyttoxins that regulate the survival of astrocytes and neurons in culture. Neurochem. Int. 25, 227-232.

Gomes, F.C.A., Paulin, D., Moura Net, V., 1999. Glial fibrillary acidic protein (GFAP): modulation by growth factors and its implication in astrocyte differentiation. Braz. J. Med. Biol. Res. 32, 619-631.

Gonzalez-Scarano, F., Baltuch, G., 1999. Microglia as mediators of inflammatory and degenerative diseases. Annu. Rev. Neurosci. 22, 219-240.

Hansen, M.B., Nielsen, S.E., Berg, K., 1989. Re-examination, and further development of a precise and rapid dye method for measuring cell growth/cell kill. J. Immunol. Meth. 119, 203-210.

Harry, G.J., Tyler, K., Lefebvre d'Hellencourt, C., Tilson, H.A., Maier, W.E., 2002. Morphological alterations and elevations in tumor necrosis factor- $\alpha$, interleukin (IL)- $1 \alpha$, and IL-6 in mixed glia cultures following exposure to trimethyltin: modulation by proinflammatory cytokine recombinant proteins and neutralizing antibodies. Toxic Appl. Pharmacol. 180, 205-218.

Hughes, J.B., 2004. Análise dos efeitos da fração de alcalóides totais extraída das vagens de Prosopis Juliflora Sw. D.C. (algaroba) sobre células gliais do sistema nervoso central [M. Sc. Thesis]. Universidade Federal da Bahia, Salvador (BA).

Hughes, J.B., Sousa, J.S., Barreto, R.A., Silva, A.R., Souza, C.S., Silva, V.D.A., Silva, B.M.P., Freitas, S.R.V.B., Costa, M.F.D., El-Bachá, R.S., Batatinha, M.J.M., Tardy, M., Velozo, E.S., Costa, S.L., 2005. Cytotoxic effects of an extract containing alkaloids obtained from Prosopis juliflora Sw. D.C. (Algaroba) pods on glioblastoma cells. Rev. Bras. Saúde Prod. Ann. 6 (1), 31-41.

Hughes, J.B., Sousa, J.S., Silva, A.M.M., Silva, V.D.A., Silva, A.R., Barreto, R.A., Granjeiro, M.S., Pinheiro, A.M., El-Bachá, R.S., Costa, Velozo, E.S., Costa, S.L., 2004. Reactional astrogliosis induced by Prosopis juliflora Sw. D.C. in astrocytes primary cultures. Rev. Vet. Bras. 24 (Suppl.), 29-30.

Kandasamy, A., William, S., Govindasamy, S., 1989. Hemolytic effects of Prosopis juliflora alkaloids. Curr. Sci. 58 (3), $142-144$.

Kanthasamy, A., Subramanian, S., Govindasamy, S., 1989. Bactericidal and fungicidal effects of Prosopis juliflora alkaloidal fraction. Indian Drugs 26 (8), 390-394.

Kaushik, J.C., Sanjay, A., Tripathi, N.N., 2002. Antifungal properties of some plant extracts against the damping-off fungi of forest nurseries. Indian J. For. 25 (3\&4), 359-361.
Lefrancois, T., Fages, C., Peschanski, M., Tardy, M., 1997. Neuritic outgrowth associated with astroglial phenotypic changes induced by antisense glial fibrillary acidic protein (GFAP) mRNA in injured neuron-astrocyte cocultures. J. Neurosci. 17 (11), 4121-4128.

Little, A.R., O'Callaghan, J.P., 2001. Astrogliosis in the adult and developing CNS: is there a role for proinflammatory cytokines? Neuro Toxicol. 22, 607-618.

Lowry, O.H., Rosenbroug, N.J., Farr, A.L., Randall, R.J., 1951. Protein measurement with the folin phenol reagent. J. Biol. Chem. 193, 265-275.

Manning, P., Cookson, M.R., Mcneil, C.J., Figlewicz, D., Shaw, P.J., 2001. Superoxide-induced nitric oxide release from cultured glial cells. Brain Res. 911, 203-210.

Mead, C., Pentreath, V.W., 1998. Hypertrophy and increased glial fibrillary acidic protein are coupled to increased protection against cytotoxicity in glioma cell lines. Toxico In vitro $12,141-152$.

Mercier, C., Decleves, X., Masseguin, C., Fragner, P., Tardy, M., Roux, F., Gabrion, J., Scherrmann, J.M., 2003. P-glycoprotein $(\mathrm{ABCB} 1)$ but not multidrug resistance-associated protein $1(\mathrm{ABCC} 1)$ is induced by doxorubicin in primary cultures of rat astrocytes. J. Neurochem. 87, 820-830.

Moises, H.W., Zoega, T., Gottesman, II., 2002. The glial growth factors deficiency and synaptic destabilization hypothesis of schizophrenia. BMC Psych. 2 (1), 8.

Mosman, T., 1983. Rapid, colorimetric assay for cellular growth and survival: application to proliferation and cytotoxicity assays. J. Immunol. Meth. 65, 55-63.

Nakano, H., Nakajima, E., Fujii, Y., Shigemori, H., Hasegawa, K., 2004a. Growth inhibitory alkaloids from mesquite (Prosopis juliflora (Sw.) DC.) leaves. Phytochemistry 65 (5), 587-591.

Nakano, H., Nakajima, E., Hiradate, S., Fujii, Y., Yamada, K., Shigemori, H., Hasegawa, K., 2004b. Structure-activity relationships of alkaloids from mesquite (Prosopis juliflora (Sw.) DC.). Plant Growth Regul. 44, 207-210.

Nasir, E., Ali, S.I., 1972. Flora of West Pakistan, first ed. Fakhri Printing Press, Karachi (IN).

Nicholson, T.E., Dibb, S., Renton, K.W., 2004. Nitric oxide mediates an LPS-induced depression of cytochrome P450 (CYP1A) activity in astrocytes. Brain Res. 1029 (2), 148-154.

Norton, W.T., Aquino, D.A., Hozumi, I., Chiu, F.C., Brosnan, C.F., 1992. Quantitative aspects of reactive gliosis. A review. Neurochem. Res. 17, 877-885.

O'Callaghan, J.P., 1991. Assessment of neurotoxicity: use of glial fibrillary acidic protein as a biomarker. Biomed. Environ. Sci. 4, 197-206.

Ott-Longoni, R., Viswanathan, N., Hesse, M., 1980. Die konstitution des alkaloides juliprosopin aus Prosopis juliflora A. DC. Helvet. Chim. Acta 63 (222), 2119-2129.

Rajkowska, G., Miguel-Hidalgo, J.J., Makkos, Z., Meltzer, H., Overholser, J., Stockmeier, C., 2002. Layer-specific reductions in GFAP-reactive astroglia in the dorsolateral prefrontal cortex in schizophrenia. Schizophr. Res. 57 (2\&3), 127-138.

Rataboul, P., Vernier, P., Faucon-Biguet, N., Mallet, J., Poulat, P., Privat, A., 1989. Modulation of GFAP mTNA levels following toxic lesions in the basal ganglia of the rat. Brain Res. 174, 283-308.

Rosenfeld, G., 1947. Corante pancrômico para hematologia e citologia clínica: Nova combinação dos componentes do May 
Grunwald e do Giemsa num só corante de emprego prático. Mem. Inst. Butantã 20, 329-335.

Salimi, K., Humpel, C., 2002. Down regulation of complement receptor 3 and major histocompatibility complex I and II antigen-like immunoreactivity accompanies ramification in isolated rat microglia. Brain Res. 946, 283-289.

Satish, S., Raveesha, K.A., Janardhana, G.R., 1999. Antibacterial activity of plant extracts on phytopathogenic Xanthomonas campestris pathovars. Lett. Appl. Microbiol. 28, 145-147.

Shearman, M.S., Hawtin, S.R., Tailor, V.J., 1995. The intracellular component of cellular 3-(4,5-dimethylthiazol-2-yl)-2,5diphenyltetrazolium bromide (MTT) reduction is specifically inhibited by $\beta$-amyloid peptides. J. Neurochem. 65, 218-227.

Silva, D.S., 1981. Substituição progressiva do farelo de trigo pela vagem da algaroba na alimentação de bovinos em engorda [M. Sc. Thesis]. Universidade Federal da Paraíba; Areia (PB).

SPA-Secretaria de Produção Animal, 1989. A algarobeira (Prosopis juliflora Sw, D.C.) no nordeste do Brasil, Brazil.

Streit, W.J., Graeber, M.B., Kreutzberg, G.W., 1988. Functional plasticity of microglia: a review. Glia 1 (5), 301-307.

Streit, W.J., Walter, S.A., Pennel, N.A., 1999. Reactive microgliosis. Progr. Neurobiol. 57, 563-581.

Sutor, B., Hagerty, T., 2005. Involvement of gap junctions in the development of the neocortex. Biochim. Biophys. Acta 1719, 59-68.
Tabosa, I.M., 2000. Intoxicação experimental pela ingestão de vagens de algaroba (Prosopis juliflora Sw. DC) em caprinos. [M. Sc. Thesis]. Universidade Federal de Mina Gerais, Belo Horizonte (MG).

Tabosa, I.M., Souza, J.C.A., Graça, D.L., Barbosa-Filho, J.M., Almeida, R.N., Riet-Correa, F., 2000. Neuronal vacuolation of the trigeminal nuclei in goats caused by ingestion of Prosopis juliflora pods (Mesquite beans). Vet. Hum. Toxicol. 42 (3), 155-158.

Tardy, M., 1991. Astrocyte et Homeostasie. Méd. Sci. 8 (7) 799-804.

Tardy, M., 2002. Role of laminin bioavailability in the astroglial permissivity for neuritic outgrowth. Ann. Braz. Acad. Sci. 74, 683-690.

Van Den Eynden, V., Cueva, E., Cabrera, O., 2003. Wild foods from Southern Ecuador. Econ. Bot. 57 (4), 576-603.

Wagner, H., Bladt, S., Zgainski, E.M., 1983. Drogen analyse. In Verlag, J., Springer, J. (Eds.), Dünnschichtchromatographie Anlyse von Arzneidrogen, first ed. Heidelberg New York Publishers, Berlin.

Wang, Z., Li, D., Liang, Y., Wang, D., Cai, N., 2002. Activation of astrocytes by advanced glycation end products: cytokines induction and nitric oxide release. Acta Pharmacol. Sin. 2002 23 (11), 974-980. 